\title{
Case of Pseudo-Bartter's Syndrome: An atypical presentation of cystic fibrosis
}

\author{
Khorasani. $E^{1}$ \\ ${ }^{1}$ Dr. Enayatollah Nemat Khorasani, MD. Paediatric Gastroentrologist, Associated Professor
}

Address for correspondence: Dr. Enayatollah Nemat Khorasani, E-mail: khorasani@dr.com

\begin{abstract}
Athree months infant who in the beginning had disease cystic fibrosis was diagonosed with pseudo-bartter's syndrome. The disease began with coughing, diarrhoea, vomiting and weakness. Investigation revealed; electrolytes showin hyponatremia $(110 \mathrm{mmol} / \mathrm{L})$ and hypokalemic $(2.6 \mathrm{mmol} / \mathrm{L})$ and hypochloremic $(63$ $\mathrm{mmol} / \mathrm{L})$ metabolic alkalosis $\left(\mathrm{HCO}_{3}=43 \mathrm{mmol} / \mathrm{L}\right)$.
\end{abstract}

Key words: Pseudo Bartter's Syndrome, Cystic fibrosis, Metabolic alkalosis.

\section{Introduction}

$D$ seudo-bartter's syndrome is a rare syndrome of electrolyte depletion, metabolic alkalosis, and failure to thrive. Hypokalemic metabolic alkalosis, encountered in variety of disease without renal tubular pathology will ultimately be corrected once the underlying disease is identified and treated. Any corrective fluid and electrolyte will therefore be a part of basic disease treatment. (PBS) can be differentiated from barter $s$ syndrome where sweat electrolyte loss is normal and the electrolyte disturbance is due to detective renal electrolyte handling.

\section{Case history}

A three months old female, born to consanguineous parents was hospitalized with a cough since the previous 10 days, there had been no prior respiratory symptomatoms, the pregnancy including the perinatal period was eventful.

There was histoty of intravenous fluid administration during the first month of her life because of weakness and poorfeeding. She was being breastfeeding two weeks before being admitted to the hospital. She then developed frequent loose stools, non bilous vomiting, abdominal distension and failure to thrive (FTT).

On examination the child weighed 4300 grams with a length of $51 \mathrm{~cm}$ and head circumference of $37 \mathrm{~cm}$ (which was in the 5 th centil for the age). Her vital signs revealed a temeprature of $37.2 \mathrm{C}$, Respiratory Rate of $60 / \mathrm{min}$, Pulse rate was 120/min, Blood Pressure was $70 / 50 \mathrm{mmHg}$. There was no facial dysmorphism and had no localizing signs on neurological examination. The systemic examination was otherwise normal.

She was resucitated with dextrose saline, intravenous antibiotics (cephalothin and amikacine), Creon $500 \mathrm{iu} / \mathrm{Kg}$ (pancreatic enzyme), Vitamins and supplements (Zn, Fe, B complex, Vit A, Vit D, Vit E) and formula caprinol (MCT oil), Chest physiothrapy, Bronchodilator as nebuliser.

She was discharged after 10 days in good condition but still without full correction of her alkalosis $(\mathrm{PH}=7.5$, $\mathrm{HCO}_{3}=38 \mathrm{meq} / \mathrm{L}, \quad \mathrm{PO}_{2}=95 \mathrm{mmg}, \quad \mathrm{PCO}_{2}=45 \mathrm{mmg}, \quad \mathrm{O}_{2}$ sat $=98 \%)$.

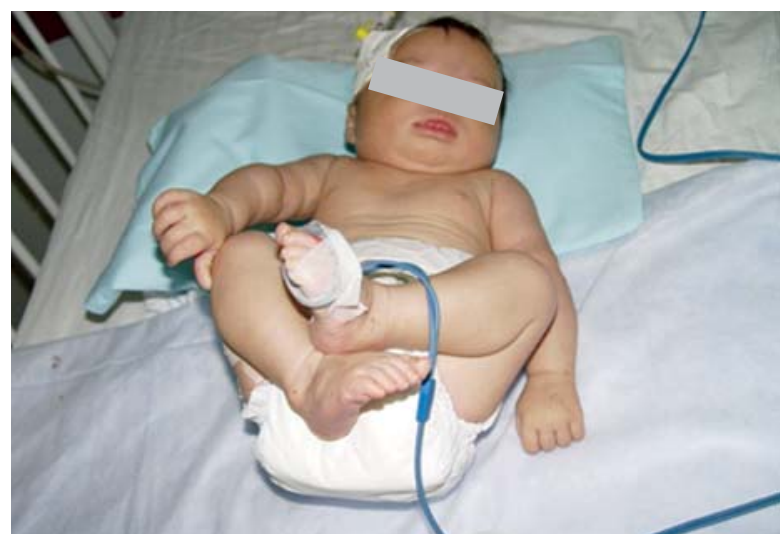

Fig 1: Photograph of the baby with pseudo-bartter's syndrome 
Laboratory Examination Reports

\begin{tabular}{|c|l|l|}
\hline Sr No. & Investigations & \multicolumn{1}{|c|}{ Results } \\
\hline 1. & Hemoglobin & $10.5 \mathrm{gm} / \mathrm{dl}$ \\
\hline 2. & White Blood Cells & $12000 / \mathrm{mm}^{3}$ \\
\hline 3. & Neutrophils: Lymphocytes: Monocytes & $42.4 \%, 39.4 \%, 18.2 \%$ \\
\hline 4. & Platelet & $488000 / \mathrm{mm}^{3}$ \\
\hline 5. & Red Blood Cell Counts & $435000000 / \mathrm{mm}^{3}$ \\
\hline 6. & Hematocrit & $32 \%$ \\
\hline 7. & $\begin{array}{l}\text { Blood Suger, Erythrocyte Sedimentation Rate (ESR), C-Reactive } \\
\text { Protein (CRP), Liver Function Tests. }\end{array}$ & All within normal limits. \\
\hline 8. & Creatinine & $1.4 \mathrm{mg} / \mathrm{dl}(0.5-1.5)$ \\
\hline 9. & Sodium (Na) & $110 \mathrm{mmol} / \mathrm{L}(135-145)$ \\
\hline 10. & Potassium (K) & $2.6 \mathrm{mmol} / \mathrm{L}(3.5-5.5)$ \\
\hline 11. & Chloride (Cl) & $63 \mathrm{mmol} / \mathrm{L}(90-110)$ \\
\hline 12. & Bicarbonate (HCO ) & $43 \mathrm{meq} / \mathrm{L}(24-28)$ \\
\hline 13. & $\begin{array}{l}\text { Blood Culture, Stool Microscopy and Stool Culture, Urinalaysis and } \\
\text { Urine Culture and Lumbar puncture. }\end{array}$ & No Abnormality Detected (NAD) \\
\hline 14. & $\begin{array}{l}\text { Metabolic profiles (ammonia, lactate, pyruvate, LDH, Reducing } \\
\text { Substance of Serum and Urine). }\end{array}$ & All normal and within normal limits. \\
\hline 15. & 24 hours Urinary Volume & $900 \mathrm{cc}$ \\
\hline 16. & Urinary Chloride & $20 \mathrm{meq} / \mathrm{L}$ \\
\hline 17. & Urinary Potassium & $18 \mathrm{meq} / \mathrm{L}$ \\
\hline 18. & Chest X Ray & Hyperairation of lungs \\
\hline 19. & Abdominal X Ray & Distention of intestinal loops \\
\hline 20. & Abdominal Ultra-Sonogram & Normal \\
\hline 21. & Sweat test×3 times & Cl=130meq/L, Na=110meq/L \\
\hline
\end{tabular}

\section{Discussion}

Cysyic fibrosis (CF) is an autosomal recessive multisistemic disease affecting 1 in 2500 newborns among Caucasians (though rare among Orientals; 1 in 90000). The disease was described first by Anderson in 1938 as cystic fibrosis of the pancrease to the point of the pancreatic exocrine function ${ }^{1,2}$. In 1953 Di sant Agnese and et.al. demonstrated that excessive salt loss occurs in the sweat of CF patients. This finding led to the use of sweat electrolytes measurement as a diagnostic tool. The major clinical characterstics of CF are pancreatic insufficiency and progressive lung disease, caused by thick and dehydrated airway mucus frequently infected with pseudomonas and staphylococcus leading to respiratory failure and CF mortality. CF is typically present in infancy with combinations of FTT and steatorrhoea and respiratory symptoms ${ }^{3,4}$.

Pseudo-bartter's syndrome (PBS) is a rare atypical presentation of CF with electrolyte depletion, alkalosis and $\mathrm{FTT}^{3,4}$.

Investigations of serum electrolytes in our patient showed hyponatremia $(110 \mathrm{mmol} / \mathrm{L})$ and hypokalemic hypocholermic metabolic alkalosis (K: $2.6 \mathrm{mmol} / \mathrm{L}, \mathrm{Cl}$ : $63 \mathrm{mmol} / \mathrm{L}, \mathrm{HCO}_{3}: 43 \mathrm{meq} / \mathrm{L}, \mathrm{PCO}_{2}: 47.3$ ). Pseudobartter's syndrome is often difficult to distinguish from bartter's syndrome.
Bartter's syndrome is an inherited renal tubular disorder characterized by hypokalemia, hypochloremic metabolic alkalosis, hyper-reninemia, hyperprostaglandinism, normal blood pressure with an increased urinary loos of $\mathrm{Na}, \mathrm{Cl}, \mathrm{K}$ and prostaglandin ${ }^{3,4}$.

The history of anamnesis of Bartter's syndrome in our patient was not evident and clinically the above characteristics of the barter syndrome and Gitelman's syndrome. (Gitelman's syndrome is another clinical type of Bartter's syndrome that characterized by hypomagnesemia, hypocalciuria, pseudohyperaldostronism (hypertension with no evidence of increased secretion of mineralocorticoids) and pseudoBartter's syndrome due to an administration of high dose of prostaglandin $\mathrm{E} 1^{5,6}$.

Nutritional requirements in CF will differ depending on: age, sex, efficacy of small intestinal absoption, respiratory status and activity level. Improved nutrition benefits growth, respiratory muscle strength and immunological status. Nutritional intervention should begin as soon as the diagnosis is made in order to prevent or resolve malnutrition. Early diagnosis and prompt treatment of CF reduce long-term morbidity and promote psychological and social adaptation to the condition $^{5,6}$. 


\section{References}

1. Bush A, Alton EwFw, Davies JC, Grie senbach U, Jaffe A. Cystic fibrosis in the $21^{\text {st }}$ century. In Bolliger CT (ed), Progress in respiratory research, Krager, 2006. P 293-298.

2. Hill CM. Diagnosis. In Hill CM (ed), Practical Guidelines for cystic fibrosis care. London, Churchill Livingstone. 1998: p 13-18.

3. Amirlak I, Dawsan KP. Bartter's syndrome: An overview. Q J Med 2000;93:207-15.
4. UK cystic fibrosis trust nutrition working Group. Nutritional management of cystic fibrosis 2002.52:101-105.

5. Sinaasappel M, Stem M, Little wood j wolfes, Steinkam PG. Nutrition in patients with cystic fibrosis: A European consensus. J Cyst Fibr 2002;2:51-7.

6. Borowitz D, Barker RD, Stallings V. Consensus report on Nutrition for pediatric patients with cystic fibrosis. J Pediatr Gastroentrol Nutr 2003;32:24659.

\section{How to cite this article?}

Khorasani. E. Case of Pseudo-Bartter's Syndrome: An atypical presentation of cystic fibrosis. J Nep Paedtr Soc 2011;31(2):121-123. 